\title{
What Are Screendance Competitions Even For? A Response to the 2015 Leeds International Film Festival Screendance Competition
}

Hamish MacPherson, Independent Artist

Keywords: screendance, competitions, curation, convention

My relationship to screendance is somewhat like my relationship to dance more generally; working with tiny little things that one could hardly think of as dance and yet I am trying to do so all the same. At the moment I have an interest in gifs, which I would argue are a very particular kind of screendance. Completely limited but all the more interesting for it. And so it is from this little corner that I try to survey contemporary screendance, looking through the peephole that is the International Screendance Competition at the Leeds International Film Festival (LIFF) 2015.

Of the 10 films $^{1}$ on show (shortlisted from 164 entries) two very different films stand out from the otherwise grey in-between.

On the one hand we have "You," directed by Graham Clayton-Chance (UK), a tribute to the late choreographer Nigel Charnock, which wins the audience vote. But it's almost a straight documentation of Dan Watson's charged performance of Charnock's thoughtful choreography. And documentation, we are told at the post-show discussion, is not screendance, so this one scrapes in.

On the other hand we have the Jury's favorite, "Choreography for the Scanner," directed by Mariam Eqbal (USA), which features an animation of a distorted scanned image of a ballet dancer. But is it dance? That's the big question right? The choice causes some surprise in the audience and one person expresses their dismay on Facebook (eliciting an amusingly extensive reply from the Jury ${ }^{2}$ ). This reminds me of people complaining that there's not enough dancing in the Place Prize. ${ }^{3}$ Both cases come down to the question of whether these are dancing or dance-making or choreography competitions. If an animation wins then I guess it's choreography but by using an image that is perhaps most emblematic of dance to a predominantly white European audience it seems to lose its nerve as if to still be in with a chance. If we say that to dance requires an intention and self awareness then an animated picture of a dancer isn't dancing any more or any less than an animated picture of a 
corpse or a tree or a triangle. But arguably you can still make a dance with things that aren't dancing and an animated human certainly feels more like a dance.

So I can see why this is the most interesting work for the judges because it raises the most questions but the internal form of the work is less interesting to me. It saunters along with a light humor and its aesthetics hark back to the past but I wonder how thought-provoking it would be for me without the frame of the competition or this writing I am doing now.

In between these two outliers we have a range of works with recognizable contemporary dance vocabulary within creative camera work, special effects, and editing. Dancing often appears as a worn metaphor for inner youth, emotion, and torment embalmed in slick camera work. The best the Jury can say for the second prize winner "Approaching the Puddle" directed by Sebastian Gimmel (Germany) is that "Whilst the form is neither challenging the dance film genre, or the content a game changer, this film is nonetheless a delightful experience for the audience." But again this is just a problem from my perspectives on dance. Many people just want something ... delightful.

I unsympathetically read most of the works as cases of dance-makers and filmmakers encountering each other far too late, so that they seem to be fascinated by the least interesting aspects of each other's worlds. Getting over-excited by the sexiness of lush images or conventionally athletic bodies. They feel like adverts or music videos but with nothing to sell. Expensive videography meets tired dance moves and normative bodies to create more clichés of what dancing is.

I come away hoping that there are people at school today that are bringing their smart phones into the dance studio so that these media are meaningfully synthesized at their roots. Maybe I am missing something but from this night I couldn't get a sense of what filmmakers and dance makers were really bringing out of each other.

This complaint is not limited to this competition and in the following months I come across similarly glossy but unimaginative examples of conventional contemporary dance in beautifully shot landscapes and the like. Stuff that has currency and visibility because it slots so easily into existing visual norms of commercial platforms, ready and willing to be assimilated into mainstream culture.

The competition raises wider questions of curation, judging and competition. Having a winning entry suggests to me that this represents the more interesting, high-quality screendance around at the moment. But the competition is self-selecting and partial, and the Jury's involvement seems to be an effort to build a wider discussion about screendance from what was available. Which feels like a bit of a compromise. 
I'm left questioning why this was a competition, rather a curated selection of films that seriously engaged with the diversity of screendance. But, again, this is just a reflection of my own priorities and interests.

I wonder then whether those films that are pushing the idea of what screendance could be, would ever put themselves forward for such a competition or whether they even see themselves as screendance. Why would they want to enter the world of screendance other than to make a (interesting, I think) philosophical point about categories of art? For I imagine that artists around the world are already consciously or unconsciously exploring choreographic ideas through film works.

But then I only have to look around at my peers and see they are already making short films and putting them online, and these are part of their practice and their work as much as dancing and writing and talking and all kinds of things. So I wonder what place there is for screendance, with all its established forms and boundaries and requirements. How does it relate to ways that people are using video technology to capture and present and produce movement right now? Genuine question.

\section{Biography}

Hamish MacPherson is a dance artist whose work is interested in how we can think about philosophical and political ideas through personal and group choreographies. He makes performances, installations, workshops, games, writings, images and other things. He has an MRes in Choreography and Performance from Roehampton University and an MA in Global Values and Contemporary Ethics from Kings College, London.

Email: macpherson.hamish@gmail.com

Website: http://www.hamishmacpherson.co.uk

\section{Notes}

1 Information about all 10 films selected is available on the LIFF Screendance Competition webpage: http://www.leedsfilm.com/films/screendance-competition/ 
2 Jury Response, Screening: LIFF Screendance Competition Facebook Event: https://www.facebook.com/events/1492156104432642/

${ }^{3}$ The Place Prize for dance is a UK contemporary dance competition hosted biennially by London dance and performance center 'The Place' and sponsored by financial service company Bloomberg.

\section{References}

Approaching the Puddle. Dir. Sebastian Gimmel. 2014.

http://www.approachingthepuddle.de/

Choreography for the Scanner - In Between Frames Series. Dir. Mariam Eqbal. 2015.

Vimeo. https://vimeo.com/128830552

You. Dir. Graham Clayton-Chance. Chor. Nigel Charnock (from the dance solo

Resurrection, 1991). 2015. Trailer on Vimeo. https://vimeo.com/155108342 